\title{
Thermal requirements, life expectancy and fertility tables of Aphis craccivora (Hemiptera: Aphididae) in Vigna unguiculata (Fabales: Fabaceae) under laboratory conditions
}

\author{
Exigências térmicas e tabelas de esperança de vida e fertilidade de \\ Aphis craccivora (Hemiptera: Aphididae) em Vigna unguiculata \\ (Fabales: Fabaceae) sob condições de laboratório
}

\author{
José Edmir Girão Filho'* (D), Luiz Evaldo de Moura Pádua' (D), Gilson Lages Fortes Portela' (D), \\ Francinalva de Morais Sousa' (D), Jayara Dayany da Costa Silva'
}

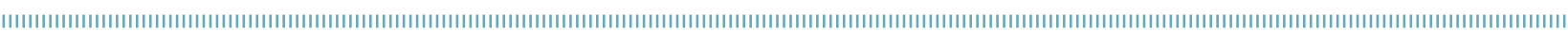

\begin{abstract}
The objective of this research was to determine the thermal requirements and develop life expectancy and fertility tables of Aphis craccivora (L.) in Vigna unguiculata (Walp.). The insects were kept in Petri dishes and fed $V$. unguiculata leaf discs (cultivar BRS-Tumucumaque) under five constant temperatures $\left(18,22,25,28\right.$ and $\left.31^{\circ} \mathrm{C}\right)$. Live and dead insects and stages of development; the onset and duration of the pre-reproductive, reproductive and post-reproductive periods; the number of nymphs per female; and the longevity of the adults were quantified daily. Based on these observations, fertility life expectancy tables were developed, and the thermal requirements of the cowpea black-aphid were determined. Increased temperature influenced all stages of insect development, as well as the pre-reproductive and post-reproductive periods and the total number of nymphs per female. The base temperature for development was $9.13^{\circ} \mathrm{C}$ with thermal development constant of $99.0 \mathrm{GD}$. The highest net reproduction rate $(\mathrm{Ro})$ was at $25^{\circ} \mathrm{C}$. At $28^{\circ} \mathrm{C}$, the greatest capacity to increase in number $\left(r_{m}\right)$ was observed, as well as the highest finite rate of increase $(\lambda)$ and the shortest time to double in number (TD). The thermal range between 22 and $28^{\circ} \mathrm{C}$ can be considered most favourable to the development of $A$. craccivora in $V$. unguiculata. Temperatures below 22 and above $28^{\circ} \mathrm{C}$ affect the fertility and survival of cowpea black-aphids. Increased temperature induces reproduction and reduces the longevity and life expectancy of $A$. craccivora in cowpeas.
\end{abstract}

KEYWORDS: insect ecology, integrated pest management, base temperature, thermal constant, black-aphid.

\begin{abstract}
RESUMO: Objetivou-se com esta pesquisa determinar as exigências térmicas e elaborar as tabelas de esperança de vida e de fertilidade de Aphis craccivora (L.) em Vigna unguiculata (Walp.). Os insetos foram mantidos em placas de Petri, alimentados com discos foliares de $V$. unguiculata, cultivar BRS-Tumucumaque, sob 5 temperaturas constantes: $18,22,25,28$ e $31^{\circ} \mathrm{C}$. Diariamente, foram quantificados os insetos vivos e mortos, o estádio de desenvolvimento, bem como o início e a duraçáo dos períodos pré-reprodutivo, reprodutivo e pós-reprodutivo, o número de ninfas por fêmea e a longevidade de adultos. Com base nessas observaçôes, elaboraram-se as tabelas de esperança de vida de fertilidade e determinaram-se as exigências térmicas do pulgão-preto do caupi. $\mathrm{O}$ aumento da temperatura influenciou todos os estádios de desenvolvimento do inseto, bem como os períodos pré-reprodutivo e pós-reprodutivo e o número total de ninfas por fêmea. A temperatura base de desenvolvimento foi de $9,13^{\circ} \mathrm{C}$, e a constante térmica de desenvolvimento, de 99,0 GD. A maior taxa líquida de reproduçáo $\left(R_{0}\right)$ foi a $25^{\circ} \mathrm{C}$. A $28^{\circ} \mathrm{C}$, constatouse a maior capacidade de aumentar em número $\left(\mathrm{r}_{\mathrm{m}}\right)$, bem como a maior razáo finita de aumento $(\lambda)$ e menor tempo para duplicar em número (TD). Pode-se considerar que a faixa térmica mais favorável ao desenvolvimento de $A$. craccivora em $V$. unguiculata está entre 22 e $28^{\circ} \mathrm{C}$. Temperaturas abaixo de 22 e acima de $28^{\circ} \mathrm{C}$ prejudicam a fertilidade e a sobrevivência do pulgáo-preto do caupi. $\mathrm{O}$ aumento da temperatura antecipa a reprodução e reduz a longevidade e esperança de vida de $A$. craccivora em feijão-caupi.
\end{abstract}

PALAVRAS-CHAVE: ecologia de insetos; manejo integrado de pragas; temperatura base; constante térmica; pulgão-preto. 


\section{INTRODUCTION}

Cowpea (Vigna unguiculata (L.) Walp.) is widely cultivated in northern and north-eastern Brazil and is traditionally planted by family farmers in small areas with low technology and low productivity. However, the cultivation of this bean has been expanding to the areas of the Brazilian cerrado, where it is planted as "safrinha" or main crop (FREIRE FILHO, 2011), and, according to CONAB (2017), with an estimated gross revenue of 4.7 billion reals in the 2016/2017 harvest.

The change in cowpea cultivation, from small (family farming) to large areas (modern agriculture), can lead to serious phytosanitary problems. According to SILVEIRA NETO et al. (1976), the main factors that regulate insect abundance are the availability of food and climate factors, especially temperature, which influences behaviour and the speed of development. Temperature is able to accelerate the population increase of a species, which can result in surpassing the level of insect damage in a smaller space of time.

Aphis craccivora (Koch, 1854) (Hemiptera: Aphididae) is one of the main phytosanitary problems encountered by cowpea producers in Africa, Asia and Latin America (SINGH; JACKAI, 1985; PETTERSSON et al., 1998).

A black-aphid infestation begins in the seedlings, and, as they develop, the insects colonize the shoots, branches, flowers and pods (BERBERET et al., 2009). In addition to the direct damage caused by the insects sucking elaborated sap, the black aphid is the main transmitter of the cucumber mosaic virus (CMV) and cucumber aphid-borne mosaic virus (CABMV), viruses that can infect cowpeas through simple or mixed infection (OLIVEIRA, 2011). Viral infection has the possibility to reduce cowpea production by $87 \%$, depending on the susceptibility of the cultivar, the virus strain and the environmental conditions (BASHIR et al., 2002).

According to CALORE et al. (2013), the success of integrated pest management implementation is dependent on basic studies of insect population dynamics, especially the identification and mode of action of the factors that regulate the growth of these populations.

One of the ways to understand the population dynamics of an insect is to determine its population parameters based on life tables, as well as determining its thermal requirements by means of the thermal constant $\mathrm{K}$ of development and the lowest base temperature of development $\mathrm{Tb}$. These parameters can be used to predict population peaks in the field, which help to identify the best season for applying a pest control technique (CIVIDANES, 2003; CIVIDANES; SOUZA, 2003).

Studies involving life tables of $A$. craccivora with different hosts are common in the literature (BERBERET et al., 2009; OBOPILE; OSITILE, 2010; ZHAOZHI et al., 2016). However, there are only two reports of their thermal requirements. One of these reports is about the alfalfa, Medicago sativa L. (Fabales: Fabaceae), performed in Oklahoma (BERBERET et al., 2009), and the other one is in Australia (BERG, 1984).

Considering that the latitude (ADDO-BEDIAKO et al., 2000), the association with endosymbiotic bacteria (BRADY et al., 2014) and the host (ZHAOZHI et al., 2016) influence the ecological parameters of black aphids, it is necessary that ecological studies be performed regionally in order to obtain more accurate data.

Thus, the objectives of this research were to determine the thermal requirements and to develop the tables of life expectancy and fertility of $A$. craccivora in cowpea ( $V$. unguiculata) in a laboratory under five constant temperatures.

\section{MATERIALS AND METHODS}

\section{Cowpea-black picking and raising of cowpea}

Aphids were collected from cowpea plants on the campus of the Universidade Federal of Piauí, Teresina, Piauí, Brazil, and then transferred to plants susceptible to cowpea (cultivar BR 17 - Gurgueia), kept in an air conditioned room $\left(25^{\circ} \mathrm{C}\right)$, under a light bench consisting of eight T10 $40 \mathrm{~W}$ daylight fluorescent lamps and eight $40 \mathrm{~W}$ incandescent lamps, with the aim of maintaining a predator-free population of aphids.

\section{Bioassay}

After stabilization of the stock population, an assay was conducted under five constant temperatures in biochemical oxygen demand (BOD) chambers with temperature and photoperiod control. The temperatures used were 18, 22, 25, 28 and $31^{\circ} \mathrm{C}$, in a 12 -hour photophase, in which 40 nymphs of 0 to 12 hours of life were maintained in Petri dishes until their death.

To obtain nymphs with a known age, 5-cm-long Petri dishes with perforated lids were used and closed with voile fabric. Each dish contained a 0.5 -cm-thick sponge and a paper filter disc, both of which were within the internal diameter of the plate and moistened with water daily - methodology adapted from VALENTE et al. (2014). In these plates, eight per temperature, a cowpea leaf disc of $3 \mathrm{~cm}$ in diameter was washed in running water, dried with paper towels, and added to each plate (eight plates per temperature). A total of five $A$. craccivora adults were conditioned from stock creation and placed onto each cowpea leaf. After 12 hours, these insects were removed, and the nymphs produced from 0 to 12 hours were placed individually into new Petri dishes, as already described. A total of 40 repetitions per temperature were included.

The plaques containing the nymphs were observed daily, and the live and dead insects, the stages of development and 
the number of exuviae were quantified, as well as the beginning and duration of the pre-reproductive, reproductive and postreproductive periods, the number of nymphs per female per day, and adult longevity. The nymphs produced were quantified and removed from the plates. The leaf discs were changed at the first sign of wilt or yellowing.

\section{Cultivation of cowpea plants for leaf supply}

For the supply of leaf discs, cowpea plants, cultivar BRSTumucumaque, were sown in $2.8 \mathrm{~L}$ pots containing a mixture of sandy soil and 5:1 vegetable soil, fertilized with $5 \mathrm{~g}$ of NPK 5-30-15 and maintained in natural conditions with daily irrigation when necessary. The leaves collected from the upper third of the plants were taken to the laboratory and washed in running water, and the leaf discs were later removed to replace the leaf discs in Petri dishes.

\section{Thermal requirements and life expectancy and fertility tables}

The hyperbola method and its reciprocal development were used to calculate the lower base development temperature $(\mathrm{Tb})$ and the thermal development constant K (CIVIDANES, 2000).

The beginning of the adult phase was considered to be the day in which the fourth exuvia was observed. The prereproductive period occurred from the fourth exuvia to the first nymph, the reproductive period included the days of parturition, and the post-reproductive period consisted of the days without parturition until the death of the adult insect.

The elaboration of the tables of life expectancy and fertility was based on the methodology of SILVEIRA NETO et al. (1976), which determined the following values: the number or rate of survivors at the beginning of age $\mathrm{x}\left(\mathrm{L}_{\mathrm{x}}\right)$; the number of individuals killed during the age range $\mathrm{x}\left(\mathrm{d}_{\mathrm{x}}\right)$; age structure $\left(\mathrm{E}_{\mathrm{x}}\right)$, which corresponds to the number of individuals living between one day and another; survival rate $\left(\mathrm{T}_{\mathrm{x}}\right)$, which represents the number of live insects beyond a given age; the life expectancy for individuals of age $\mathrm{x}\left(\mathrm{e}_{\mathrm{x}}\right)$; and the probability of death at age $x\left(100 q_{x}\right)$, which indicates the probability of death occurring before the time established in $\mathrm{E}_{\mathrm{x}}$, according to Equations 1, 2 and 3:

$\mathrm{E}_{\mathrm{x}}=\left[\mathrm{L}_{\mathrm{x}}+\left(\mathrm{l}_{\mathrm{x}}+1\right)\right] / 2$

$e_{x}=T_{x} / L_{x}$

$100 \mathrm{q}_{\mathrm{x}}=\left(\mathrm{d}_{\mathrm{x}} / \mathrm{L}_{\mathrm{x}}\right) * 100$

The values of the net reproduction rate $\left(\mathrm{R}_{0}\right)$, the time interval between each generation $(T)$, the innate ability to increase in number $\left(\mathrm{r}_{\mathrm{m}}\right)$, the ratio $(\lambda)$, defined as the number of times the population multiplies in a unit of time, and the necessary time for the population to double in number of individuals (TD) were calculated as Equations 4, 5 and 6:

$\mathrm{R}_{0}=\Sigma\left(\mathrm{m}_{\mathrm{x}}\left(\Sigma \mathrm{m}_{\mathrm{x}}^{*} 1_{\mathrm{x}}\right), \mathrm{r}_{\mathrm{m}}=\log \mathrm{R}_{0} / \mathrm{T}^{*} 0.4343\right.$

$\lambda=\operatorname{anti} \log \left(\mathrm{r}_{\mathrm{m}} * 0.4343\right)$

$\mathrm{TD}=\operatorname{Ln}(2) / \mathrm{r}_{\mathrm{m}}$

In which:

$\mathrm{m}_{\mathrm{x}}=$ number of females produced per female at age $\mathrm{x}$;

$1_{x}=$ survival rate at age $x$, and $m_{x}$;

$* 1_{x}=$ total number of females produced per female during the time interval.

The survival curves obtained at the temperatures tested were statistically analysed using the G-test $(\mathrm{p}<0.1)$, and the population parameters obtained in the fertility life tables were analysed using the jack-knifed method (MAIA et al., 2000).

The experimental design was completely randomized, with treatments consisting of five treatments and 40 repetitions, considering each nymph as a repetition. The computer system TabVida, by PENTEADO (2007), and the software Assistat were used for the analysis of the data.

\section{RESULTS AND DISCUSSION}

\section{Nymphal stages, nymphal period, longevity and biological cycle}

The temperature increase from 18 to $31^{\circ} \mathrm{C}$ inversely influenced the developmental period of all nymphal stages, the nymphal period, longevity and the biological cycle of cowpea blackaphids, reducing the nymphal period by $63 \%$, the longevity of adults by $44 \%$ and the biological cycle by $54.5 \%$ (Table 1 ). This inversely proportional relationship was observed by other authors and it is because insects are pecilothermic animals that maintain their body temperature close to the temperature of their environment (CIVIDANES, 2003; BARBOSA et al., 2011).

The data obtained from the literature regarding the development time of $A$. craccivora are quite variable, suggesting that the development time of $A$. craccivora in cowpea is influenced by the degree of resistance of the cultivar used and possible genetic differences in the population of black-aphids, highlighting the importance of regional studies.

The effect of three cultivars of cowpea on black aphid development was evaluated by VALENTE et al. (2014) and ranged from 1.12 to 1.96 days for the first nymphal stage, 
1.12 to 1.24 days for the second stage, 0.64 to 0.92 days for the third stage, and 0.28 to 0.56 days for the fourth instar, and a nymphal period ranging from 3.16 to 4.68 days at $25^{\circ} \mathrm{C}$ in susceptible and resistant cultivars. HAFIZ (2006) tested nine cowpea cultivars for black aphid infestation and obtained values ranging from 1.6 to $2.2,1.5$ to $2.0,1.5$ to 1.7 and 1.1 to 1.7 days, respectively, for the first, second, third and fourth instars at $25^{\circ} \mathrm{C}$.

Regarding the effect of temperature on the longevity of the black aphid, the same inversely proportional pattern was reported by BERBERET et al. (2009), varying from 14.7 to 32.2 days at 29.4 and $18.3^{\circ} \mathrm{C}$, respectively, in alfalfa (Medicago sativa L.).

In relation to the biological cycle of the cowpea black-aphid, JALALIPOUR et al. (2017) observed a cycle of 24.2 days at $25^{\circ} \mathrm{C}$ in false acacia (Robinia pseudoacacia). BERBERET et al. (2009) recorded the times of 32.2 days at $18^{\circ} \mathrm{C}, 19.3$ days at $23.9^{\circ} \mathrm{C}$ and 14.7 days at $29.4^{\circ} \mathrm{C}$ in alfalfa. DE LA PAVA; SEPÚLVEDA-CANO (2015) recorded the time of 16.5 days at $28^{\circ} \mathrm{C}$ in cowpea, which was a higher value than the one verified in this research and that can be explained, in part, by the different hosts used (ZHAOZHI et al., 2016) and the different levels of and origin of the aphid population used (BRADY et al., 2014).

\section{Pre-reproductive, reproductive, post-reproductive and fertility period}

The increased temperature statistically influenced the prereproductive and post-reproductive periods, the number of nymphs per female and the number of nymphs per female per day (Table 2).

Reproduction of the aphids began within the first 24 hours after the fourth ecdysis at all tested temperatures, except for $18^{\circ} \mathrm{C}$, which started one day later. The post-reproductive period was only observed at 18 days and $31^{\circ} \mathrm{C}$, also for approximately one day (Table 2).

BARBOSA et al. (2011) found that the reproductive period of Myzus persicae (Sulzer, 1776) (Homoptera: Aphididae) in peppers at temperatures of 20 and $25^{\circ} \mathrm{C}$ began on the same day that the aphid became an adult. At 15 and $30^{\circ} \mathrm{C}$, reproduction started one day after the emergence of adults, corroborating the results presented. From the ecological point of view, this characteristic is important for species with short longevity that are susceptible to temporal changes, as that is the case with aphids (ILHARCO, 1992).

Although the reproductive period was statistically the same at all temperatures, there was $43 \%$ reduction in the

Table 1. Mean development time (days $\pm \mathrm{SE}$ ) of Aphis craccivora in Vigna unguiculata at different constant temperatures and a 12-hour photophase.

\begin{tabular}{lccccc} 
Biological parameters & \multicolumn{5}{c}{ Temperature $\left({ }^{\circ} \mathrm{C}\right)$} \\
\cline { 2 - 6 } & 18 & 22 & 25 & 28 & 31 \\
\hline $1^{\circ}$ instar & $3.7 \pm 0.18 \mathrm{a}$ & $2.1 \pm 0.05 \mathrm{~b}$ & $1.6 \pm 0.09 \mathrm{c}$ & $1.1 \pm 0.06 \mathrm{~d}$ & $1.1 \pm 0.05 \mathrm{~d}$ \\
\hline $2^{\circ}$ instar & $3.0 \pm 0.20 \mathrm{a}$ & $1.6 \pm 0.09 \mathrm{~b}$ & $1.3 \pm 0.08 \mathrm{bc}$ & $1.5 \pm 0.07 \mathrm{c}$ & $1.1 \pm 0.05 \mathrm{c}$ \\
\hline $3^{\circ}$ instar & $3.3 \pm 0.21 \mathrm{a}$ & $1.7 \pm 0.10 \mathrm{~b}$ & $1.2 \pm 0.07 \mathrm{c}$ & $1.1 \pm 0.06 \mathrm{c}$ & $1.2 \pm 0.08 \mathrm{c}$ \\
\hline $4^{\circ}$ instar & $3.3 \pm 0.20 \mathrm{a}$ & $2.0 \pm 0.11 \mathrm{~b}$ & $1.7 \pm 0.08 \mathrm{bc}$ & $1.5 \pm 0.1 \mathrm{c}$ & $1.6 \pm 0.11 \mathrm{bc}$ \\
\hline Nymphal period & $13.4 \pm 0.32 \mathrm{a}$ & $7.4 \pm 0.11 \mathrm{~b}$ & $5.8 \pm 0.12 \mathrm{c}$ & $4.9 \pm 0.12 \mathrm{~d}$ & $4.9 \pm 0.11 \mathrm{~d}$ \\
\hline Longevity & $11.5 \pm 1.97 \mathrm{a}$ & $11.5 \pm 1.68 \mathrm{a}$ & $10.1 \pm 1.42 \mathrm{a}$ & $6.8 \pm 0.44 \mathrm{a}$ & $6.4 \pm 0.4 \mathrm{a}$ \\
\hline Biological cycle & $24.9 \pm 1.9 \mathrm{a}$ & $18.9 \pm 1.67 \mathrm{~b}$ & $15.9 \pm 1.42 \mathrm{bc}$ & $11.8 \pm 0.4 \mathrm{~cd}$ & $11.3 \pm 0.40 \mathrm{~d}$ \\
\hline
\end{tabular}

Means on the same line followed by the same letter do not differ statistically from each other, as determined by the Tukey test $(p<0.01)$. SE: standard error.

Table 2. Mean time of pre-breeding, reproduction, and post-reproduction periods, and the mean number of nymphs per female (days $\pm \mathrm{SE}$ ) of Aphis craccivora at different constant temperatures and a 12-hour photophase in cowpeas.

\begin{tabular}{lccccc} 
Biological parameters & \multicolumn{5}{c}{ Temperature ${ }^{\circ} \mathrm{C}$} \\
\cline { 2 - 6 } & 18 & 22 & 25 & 28 & 31 \\
Pre-reproductive period & $1.0 \pm 0.2 \mathrm{a}$ & $0.1 \pm 0.1 \mathrm{~b}$ & $0.1 \pm 0.0 \mathrm{~b}$ & $0.04 \pm 0.0 \mathrm{~b}$ & $0.1 \pm 0.1 \mathrm{~b}$ \\
\hline Reproductive period & $9.7 \pm 1.8 \mathrm{a}$ & $10.9 \pm 1.5 \mathrm{a}$ & $9.2 \pm 1.3 \mathrm{a}$ & $6.3 \pm 0.7 \mathrm{a}$ & $4.7 \pm 0.5 \mathrm{a}$ \\
\hline Post-reproductive period & $1.2 \pm 0.4 \mathrm{ab}$ & $0.8 \pm 0.3 \mathrm{ab}$ & $0.8 \pm 0.3 \mathrm{ab}$ & $0.2 \pm 0.1 \mathrm{~b}$ & $1.6 \pm 0.5 \mathrm{a}$ \\
\hline Nymphs per female & $26.2 \pm 5.9 \mathrm{bc}$ & $54.4 \pm 8.4 \mathrm{ab}$ & $60.5 \pm 7.4 \mathrm{a}$ & $47.5 \pm 5.1 \mathrm{ab}$ & $16.0 \pm 3.5 \mathrm{c}$ \\
\hline Nymphs per female per day & $2.7 \pm 0.6 \mathrm{c}$ & $4.99 \pm 0.7 \mathrm{~b}$ & $7.2 \pm 0.8 \mathrm{a}$ & $7.5 \pm 0.8 \mathrm{a}$ & $3.4 \pm 0.7 \mathrm{bc}$ \\
\hline
\end{tabular}

Means followed by the same letter on the same line were not significantly different from each other as determined the Tukey test $(p<0.05)$. SE: standard error. 
number of reproductive days at $31^{\circ} \mathrm{C}$ compared to that for aphids kept at $22^{\circ} \mathrm{C}$. However, the number of nymphs per female was highly influenced by temperature, increasing linearly from 18 to $25^{\circ} \mathrm{C}$ and decreasing from 25 to $31^{\circ} \mathrm{C}$. It was observed that at 18 and $31^{\circ} \mathrm{C}$ there was reduction of 56.7 and $73.5 \%$, respectively, in the production of nymphs per female relative to $25^{\circ} \mathrm{C}$. BERBERET et al. (2009) also observed increase in the reproductive period and decrease in the number of nymphs per female with decreased temperature for $A$. craccivora raised in alfalfa. However, BERBERET et al. (2009) found variation of 25.1 days at $18.3^{\circ} \mathrm{C}$ and 12.4 days at $29^{\circ} \mathrm{C}$, values which were higher than those ones found in this study and by VALENTE et al. (2014) at $25^{\circ} \mathrm{C}$, who observed 4- and 7-day reproductive period in cowpeas.

Although there are differences between the results presented in this research with those of BERBERET et al. (2009) and VALENTE et al. (2014) in relation to the reproductive period, when comparing the number of nymphs per female, we observed similarities. BERBERET et al. (2009) noticed the production of nymphs per female ranging from 20 to 82 , with 0.6 to 5.9 nymphs per female per day. VALENTE et al. (2014) recorded the production of nymphs per female ranging from 15.4 in a resistant cultivar to 85.8 nymphs per female in susceptible cultivars, with 1.72 to 5.73 daily production of nymphs, corroborating the presented values in Table 2.

In general, it was observed that there is an inversely proportional relationship between reproductive period and nymphs produced per female per day in the thermal range of 22 to $28^{\circ} \mathrm{C}$, corroborating the data presented by BERBERET et al. (2009). These results suggest that there are probably adaptive differences among the studied aphid populations.

\section{Thermal requirements}

The linear portion of the development curve versus temperature (Fig. 1), obtained at constant temperatures, allowed for the calculation of the lower base temperature $(\mathrm{Tb})$ and the thermal constant $(\mathrm{K})$ for all stages of development of A. craccivora (Table 3 ).

BERBERET et al. (2009) in Oklahoma found that A. craccivora failed to reach reproductive status when raised in alfalfa at $7.2^{\circ} \mathrm{C}$ and calculated a lower development temperature of $7.1^{\circ} \mathrm{C}$ with a thermal constant $\mathrm{K}$ of $100 \mathrm{GD}$ for the nymphal development period. This result was consistent with the thermal constant presented in this work (99 GD). BERG (1984) studied the thermal requirements of cowpea black-aphid in different hosts in Australia and obtained the base temperature of $8.1^{\circ} \mathrm{C}$.

The differences observed in the thermal development constant and the base temperature of the black-aphid boar of the cowpea can be explained in part by the theory of functional prediction, which postulates that a high value for the development threshold and a small value for the thermal sum are expected for species more adapted to hot (tropical) areas than for those adapted to cold (temperate) areas (TRUDGILL; PERRY, 1994; TRUDGILL, 1995).

In this study, it was verified that the development time of A. craccivora decreased linearly up to $25^{\circ} \mathrm{C}$. From this temperature, there was tendency for stabilization, with decrease in the development velocity between 28 and $31^{\circ} \mathrm{C}$, which is similar to what was reported by CIVIDANES (2003) and ZHAOZHI et al. (2016). According to WILSON; BARNETT (1983), this stabilization, and even a slight increase in the development time with increased temperature, may be related to the proximity of the upper base temperature of development Ts. According to CHEN et al. (2013), at the constant temperature of $35^{\circ} \mathrm{C}$, only $16 \%$ of

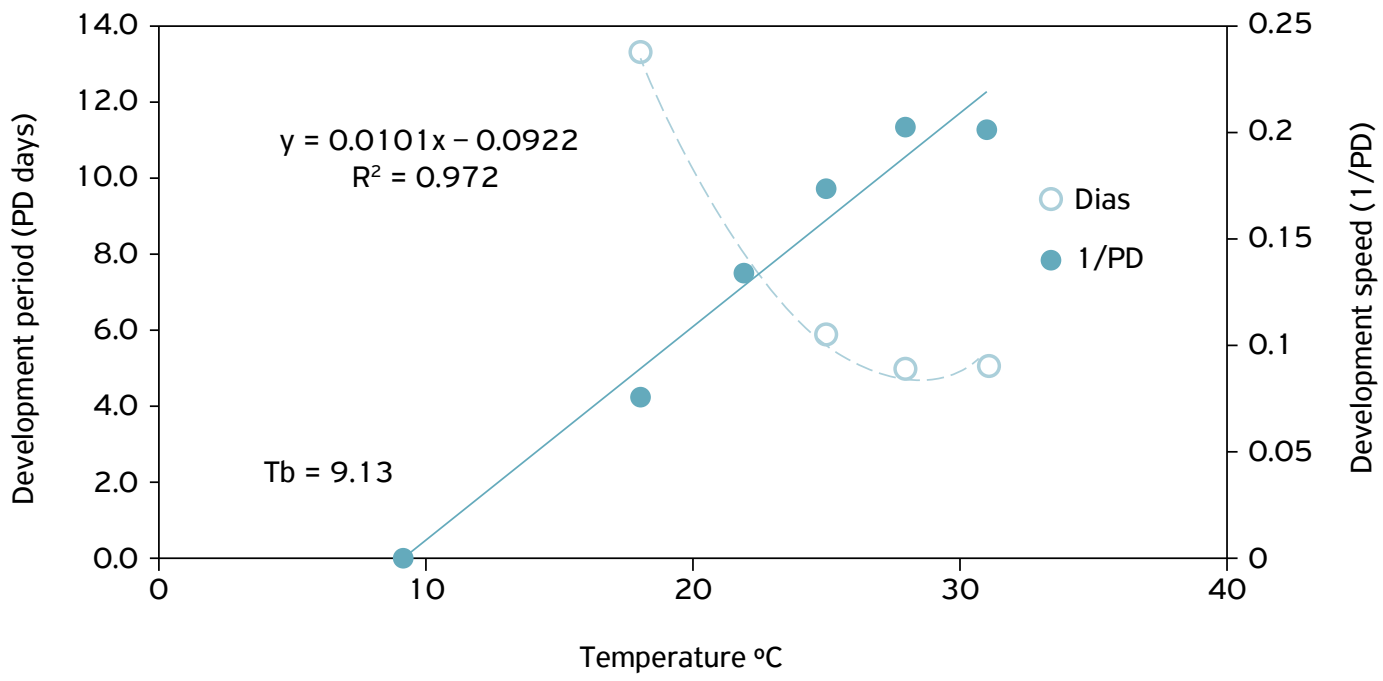

Figure 1. Relationship between temperature, time (days) and developmental speed of the Aphis craccivora nymphal period in cowpeas kept at the constant temperatures of $18,22,25,28$ and $32^{\circ} \mathrm{C}$ with a photophase of 12 hours. 
the black-aphid nymphs of cowpea reached adulthood when kept in Vigna unguiculata sesquipedalis (L.), and they did not reproduce, corroborating the hypothesis that this temperature is near or above the Ts.

It can be considered in general that temperatures above 22 and below $28^{\circ} \mathrm{C}$ are within the thermal range that is most favourable to the development of $A$. craccivora, because the insects presented the highest fertility rates and a shorter time period, and 18 and $31^{\circ} \mathrm{C}$ as sub-optimal temperatures, causing reduction in the development speed and birth rate (Tables 2 and 4). These results differ from those observed by BERBERET et al. (2009), which stated that the optimum temperature range of $A$. craccivora development is between 18 and $24^{\circ} \mathrm{C}$. However, it is possible that these biological differences may be due to the different biotypes of $A$. craccivora analysed, as well as the differences between endosymbiont organisms, which may interfere with insect biological rates (BRADY et al., 2014).

\section{Life table and fertility demographic parameters}

The net reproduction rate, the number of times the population increases in each generation (Ro), increased linearly up to $25^{\circ} \mathrm{C}$. From this temperature, a slight decrease was observed at $28^{\circ} \mathrm{C}$ and an abrupt drop at $31^{\circ} \mathrm{C}$, with reduction of $80.6 \%$ over $25^{\circ} \mathrm{C}$ (Table 4 ). These results corroborate those presented by BARBOSA et al. (2011), who observed reduction in the net reproductive rate of $M$. persicae at extreme temperatures of 15 and $30^{\circ} \mathrm{C}$.

The temperature negatively influenced the time interval between the generations in a linear fashion, being that at $18^{\circ} \mathrm{C}$ this period was $59.63 \%$ sooner compared to at $28^{\circ} \mathrm{C}$. This fact is directly related to the lower base temperature $(\mathrm{Tb})$, the upper base temperature (Ts), and the thermal constant (K) (Table 3), considering that poikilothermic animals need to accumulate an amount of energy, $x$ (degree-day), to complete or reach a stage of development. Thus, the greater the difference within the optimum thermal range, between $\mathrm{Tb}$ and the temperature at which the insect is, the more energy is accumulated and the faster the development occurs (CIVIDANES, 2000).

CHEN et al. (2013) found the opposite of $\mathrm{T}$ when the aphids were confined to $28.6,30.0$, or $32.5^{\circ} \mathrm{C}$ in Vigna sesquipedalis. This difference can be explained by the mean of the Ts of development, in which WILSON; BARNETT (1983) could slow the rate of development when the ambient temperature approached the upper development threshold. In addition, according to ZHAOZHI et al. (2016), the host also has an influence. FERREIRA (2015) observed a T ranging from 5.3 to 8.0 days for $A$. craccivora that were kept in cultivars of cowpeas (temperatures ranging from 28.7 to $35^{\circ} \mathrm{C}$ in the greenhouse) and were susceptible and resistant at the values within the ranges presented in this research. Thus, the relationship between temperature and cultivar is an important component that must be considered in phytosanitary management programmes of cowpea black-aphids.

Table 3. Base temperature (Tb), thermal constant (K), determination coefficient and equation of the development rate of Aphis craccivora in cowpeas kept at the constant temperatures of $18,22,25,28$ and $32^{\circ} \mathrm{C}$ with a photophase of 12 hours.

\begin{tabular}{lcccc} 
Stage of development & Tb ${ }^{\circ} \mathrm{C}$ & K GD & $\mathbf{R}^{2}$ & Equation \\
\hline I stadium & 12.8 & 18.58 & 0.99 & $\mathrm{y}=0.054 \mathrm{x}-0.67$ \\
\hline II stadium & 9.3 & 21.88 & 0.94 & $\mathrm{y}=0.048 \mathrm{x}-0.42$ \\
\hline III stadium & 9.0 & 23.31 & 0.81 & $\mathrm{y}=0.043 \mathrm{x}-0.39$ \\
\hline IV stadium & 3.5 & 40.00 & 0.82 & $\mathrm{y}=0.025 \mathrm{x}-0.087$ \\
\hline Nymphal period & 9.1 & 99.00 & 0.97 & $\mathrm{y}=0.0101 \mathrm{x}-0.0922$ \\
\hline Biological cycle & 9.0 & 243.9 & 0.98 & $\mathrm{y}=0.0041 \mathrm{x}-0.037$ \\
\hline
\end{tabular}

Table 4. Population and biological parameters ( \pm SE) of Aphis craccivora in cowpeas under constant temperatures.

\begin{tabular}{|c|c|c|c|c|c|}
\hline \multirow{2}{*}{ Biological parameters } & \multicolumn{5}{|c|}{ Temperature ${ }^{\circ} \mathrm{C}$} \\
\hline & $18(n=21)$ & $22(n=27)$ & $25(n=30)$ & $28(n=25)$ & $31(n=18)$ \\
\hline $\mathrm{R}_{\mathrm{o}}$ & $12.4 \pm 0.6 a$ & $32.6 \pm 1.2 b$ & $39.13 \pm 1.3 c$ & $29.4 \pm 1.2 b$ & $7.59 \pm 0.1 \mathrm{e}$ \\
\hline $\mathrm{T}$ & $19.0 \pm 0.9 a$ & $12.6 \pm 0.5 b$ & $9.77 \pm 0.5 c$ & $7.67 \pm 0.3 d$ & $6.73 \pm 0.0 d$ \\
\hline$r_{m}$ & $0.13 \pm 0.0 a$ & $0.28 \pm 0.0 a b$ & $0.38 \pm 0.0 a b$ & $0.44 \pm 0.0 a b$ & $0.30 \pm 0.0 b$ \\
\hline$\lambda$ & $1.14 \pm 0.1 \mathrm{a}$ & $1.32 \pm 0.0 a$ & $1.46 \pm 0.0 a$ & $1.55 \pm 0.1 \mathrm{a}$ & $1.35 \pm 0.0 a$ \\
\hline TD & $5.23 \pm 0.3 a$ & $2.50 \pm 0.1 b$ & $1.85 \pm 0.1 b c$ & $1.57 \pm 0.1 c$ & $2.3 \pm 0.0 b c$ \\
\hline
\end{tabular}

Means followed by the same letter in the same row were not significantly different as determined by the Student's $t$ test $(p<0.05)$.

$R_{0}$ : net reproduction rate; T: time between generations; $r_{m}$ : innate ability to increase in number; $\lambda$ : finite rate of increase; TD: time for population to double; $n$ : number of insects analysed; SE: standard error. 
The innate ability to increase in number $\left(\mathrm{r}_{\mathrm{m}}\right)$, as well as the finite ratio $(\lambda)$, increased linearly with increasing temperatures up to $28^{\circ} \mathrm{C}$. At $31^{\circ} \mathrm{C}$, there was decrease in these values, indicating that above this temperature the speed of population growth decreases, as well as the number of females added to the population, demonstrating the effect of thermal stress and corroborating the results presented by CHEN et al. (2013).

A. craccivora is considered a cosmopolitan insect, which is therefore adapted to the most diverse thermal conditions. However, while temperatures below 22 and above $28^{\circ} \mathrm{C}$ decrease its net reproduction rate, they do not impede population growth, considering the positive values of $r_{m}$.

\section{Survival and specific fertility}

The life expectancy ( $\mathrm{e}_{\mathrm{x}}$ ) of $A$. craccivora linearly decreased with increased temperature, with values of $21,18,15,9$ and 8 days at temperatures of $18,22,25,28$ and $31^{\circ} \mathrm{C}$, respectively (Fig. 2), which corroborated the results from BARBOSA et al. (2011). At 28 and $31^{\circ} \mathrm{C}$, it was observed that mortality affected the population as a whole, including nymphs and adults, which could be characterized as a type II pattern curve. At temperatures of 18,22 and $25^{\circ} \mathrm{C}$, there was increase in mortality in adults after the fifth day, which could be characterized as a type I pattern curve (Fig. 2). The same survival curve pattern was observed by CHEN et al. (2013), who reported type II patterns at the highest temperature tested, $35^{\circ} \mathrm{C}$.

Statistically, the survival curves of the aphids created at 28 and $31^{\circ} \mathrm{C}$ were the same $(\mathrm{p}=0.006)$, as determined by the G-test (chi-square $0.1 \%$ ), and all the other temperature combinations were different. A mortality rate of $50 \%$ was observed between days 20.5 and 21.5 at $18^{\circ} \mathrm{C}$, between days 16.5 and 17.5 at $22^{\circ} \mathrm{C}$, between days 13.5 and 14.5 at $25^{\circ} \mathrm{C}$, between days 11.5 and 12.5 at $28^{\circ} \mathrm{C}$ and at 8.5 days at $31^{\circ} \mathrm{C}$ (Fig. 2). CHEN et al. (2013) observed this same pattern for A. craccivora reared on $V$. unguiculata sesquipedalis, submitted
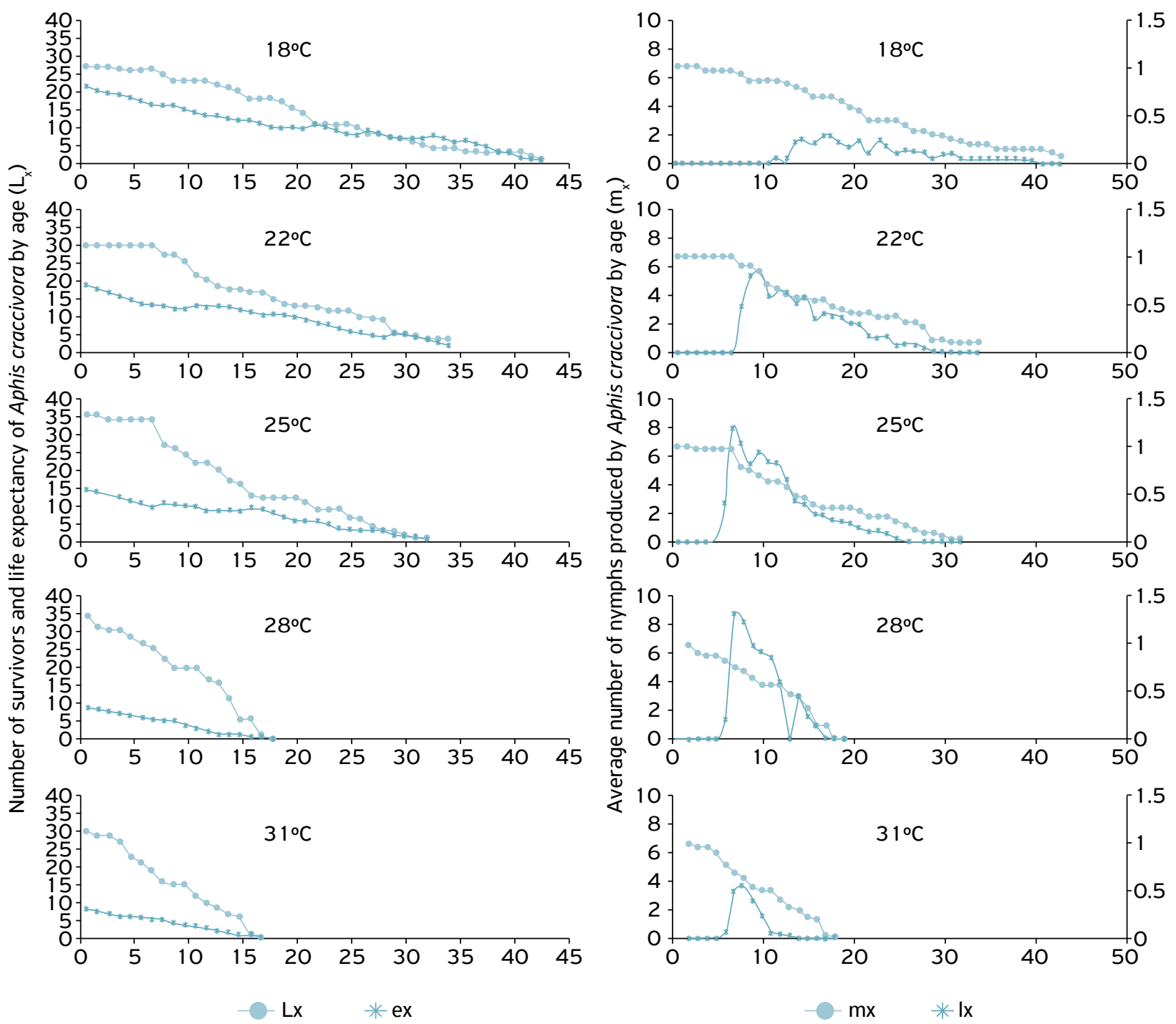

Figure 2. Survival curves $\left(L_{x}\right)$, life expectancy $\left(e_{x}\right)$ and specific fertility $\left(m_{x}\right)$ of $A$ phis craccivora in cowpeas under constant temperatures. 
to constant temperatures and oscillating; at constant temperatures, a $50 \%$ mortality was observed on the $16^{\text {th }}$ day at $28.6^{\circ} \mathrm{C}$ and on the $7^{\text {th }}$ day at $35^{\circ} \mathrm{C}$.

The influence of temperature on the reproduction of A. craccivora can also be observed in Figure 2, in which the relationship between the average number of nymphs produced per female $\left(m_{x}\right)$ per age range is shown. It was observed that the aphids kept at $18^{\circ} \mathrm{C}$ began to reproduce between day (x) 10.5 and 11.5 , with a mean of 0.3 nymphs per female, reaching their breeding peak between 16.5 and 17.5 days, with the average daily production of two nymphs per female. At $22^{\circ} \mathrm{C}$, the insects began breeding in the range of 6.5 to 7.5 days, with production of 3.1 nymphs per female. The breeding peak at this temperature was reached in the range of 8.5 to 9.5 days, with the average yield of 5.9 nymphs per female. When kept at $25^{\circ} \mathrm{C}$, the start of reproduction was observed at 4.5 days, with the peak at 6.5 days, with mean yields of 0.1 and 7.8 nymphs per female, respectively. At $28^{\circ} \mathrm{C}, 1.5$ nymph per female was produced between 3.5 and 4.5 days, with the peak at 5.5 days with rate of 8.8 nymphs per female. Finally, it was observed that at $31^{\circ} \mathrm{C}$ the insects started reproduction in the age range of 3.5 to 4.5 days, with $m_{x}$ of 0.4 and the highest $m_{x}$ rate between 5.5 and 6.5 days, with a mean of 3.6 nymphs per female (Fig. 2). In general, a decrease in the time to the beginning of reproduction, as well as the time to reach the reproductive peak, was observed with increased temperature: at $28^{\circ} \mathrm{C}$ the highest $m_{x}$ rate was obtained in a smaller amount of time. According to SILVEIRA NETO et al. (1976), the optimal temperature is one in which the insects produce a greater number of descendants in a shorter time. However, this high production of nymphs at $28^{\circ} \mathrm{C}$ is balanced by higher mortality and lower life expectancy of the individuals (Fig. 2).

\section{CONCLUSIONS}

Aphis craccivora completes its development accumulating 99.0 GD, with a lower base temperature of $9.13^{\circ} \mathrm{C}$.

Temperatures above 22 and below $28^{\circ} \mathrm{C}$ are more favourable to population growth and development of $A$. craccivora in cowpeas.

Temperatures below 22 and above $28^{\circ} \mathrm{C}$ reduce the biotic potential of $A$. craccivora.

An increase in temperature, within the most favourable range, anticipates reproduction and reduces the longevity and life expectancy of $A$. craccivora in cowpeas.

\section{ACKNOWLEDGMENTS}

The authors would like to thank the Coordination of Improvement of Higher Level Personnel (CAPES), for granting the scholarship to the first author.

To Dr. Regina Célia Zonta de Carvalho, for identification of the aphid species.

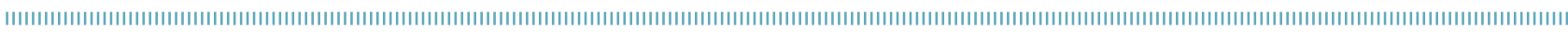
REFERENCES

ADDO-BEDIAKO, A.; CHOWN, S.L.; GASTON, K.J. Thermal tolerance, climatic variability and latitude. Proceedings of the Royal Society of London, v.267, p.739-745, 2000. https://dx.doi.org/10.1098/ rspb.2000.1065

BARBOSA, L.R.; CARVALHO, C.F; AUAD, A.M.; SOUZA, B.; BATISTA, E.S.P. Tabelas de esperança de vida e fertilidade de Myzus persicae sobre pimentão em laboratório e casa de vegetação. Bragantia, Campinas, v.70, n.2, p.375-382, 201 1. http://dx.doi. org/10.1590/SO006-87052011000200018

BASHIR, M.; AHMAD, Z.; GHAFOOR, A. Cowpea aphid-borne potyvirus: a review. International Journal of Pest Management, v.48, n.2, p.155168, 2002. https://dx.doi.org/10.1080/09670870110118722

BERBERET, R.C.; GILES, K.L.; ZARRABI, A.A.; PAYTON, M.E. Development, reproduction, and within-plant infestation patterns of Aphis craccivora (Homoptera: Aphididae) on alfalfa. Environmental Entomology, v.38, n.6, p. 1765-1771, 2009. https://dx.doi. org/10.1603/022.038.0630
BERG, G.N. The effect of temperature and host species on the population growth potential of the cowpea aphid, Aphis craccivora Koch (Homoptera: Aphididae). Australian Journal of Zoology, v.32, n.3, p.345-352, 1984. https://doi.org/10.1071/ Z09840345

BRADY, C.M.; ASPLEN, M.K.; DESNEUX, N.; HEIMPEL, G.E.; HOPPER, K.R.; LINNEN, C.R.; OLIVER, K.M.; WULFF, J.A.; WHITE, J.A. Worldwide populations of the Aphid Aphis craccivora are Infected with diverse facultative bacterial symbionts. Microbiology Ecology, v.67, p.195-204, 2014. https://dx.doi.org/10.1007/ s00248-013-0314-0

CALORE, R.A.; GALLI, J.C.; PAZINI, W.C.; DUARTE, R.T.; GALLI, J.A. Fatores climáticos na dinâmica populacional de Anastrepha spp. (Diptera: Tephritidae) e de Scynmus spp. (Coleoptera: Coccinellidae) em um pomar experimental de goiaba Psidium guajava L. Revista Brasileira de Fruticultura, v.35, n.1, p.67-74, 2013. http://dx.doi.org/10.1590/ So100-29452013000100009 
CHEN, C.Y.; CHIU, M.C.; KUO, M.H. Effect of warming with temperature oscillations on a low-latitude aphid, Aphis craccivora. Bulletin of Entomological Research, v.103, n.4, p. 406-413, 2013.https:// doi.org/10.1017/S0007485312000867

CIVIDANES, F.J. Uso de graus-dia em entomologia, com particular referência ao percevejo da soja. Jaboticabal: Funep, 2000. $31 \mathrm{p}$

CIVIDANES, F.J. Exigências térmicas de Brevicoryne brassicae e previsão de picos populacionais. Pesquisa Agropecuária Brasileira, v.38, n.5, p.561-566, 2003. http://dx.doi.org/10.1590/ so $100-204 \times 2003000500002$

CIVIDANES, F.J.; SOUZA, V.P. Exigências térmicas e tabelas de vida de fertilidade de Myzus persicae (Sulzer) (Hemiptera: Aphididae) em laboratório. Neotropical Entomology, v.32 n.3, p.413-419, 2003 http://dx.doi.org/10.1590/S1519-566X2003000300005.

COMPANHIA NACIONAL DE ABASTECIMENTO (CONAB) Acompanhamento da safrabrasileira; grãos. V.5-SAFRA 2017/18-N.3Terceiro levantamento, dezembro, 2017. Available from: $<\mathrm{https}$ ://www. conab.gov.br/info-agro/safras/graos/boletim-da-safra-de-graos/item/ download/16714_d7a4ad363319050e2bce9b695cf7bb09>. Accessed on: Dec. 27, 2017.

DE LA PAVA S.N.; SEPÚLVEDA-CANO, P.A. Biología del áfido negro (Aphis craccivora: Aphididae) sobre fríjol caupi (Vigna unguiculata, Fabaceae). Acta Biológica Colombiana, v.20, n.3, p.93-97, 2015. http://dx.doi.org/10.15446/abc.v20n3.43064

FERREIRA, A.D.C.L. Preferência de Aphis craccivora, Koch por variedades locais de feijão de corda oriundas de Pentecostes, Ceará. 2015. 47f. Dissertation (Mestrado em Agronomia/Fitotecnia) - Universidade Federal do Ceará, Ceará, 2015.

FREIRE FILHO, F.R. (Ed.). Feijão-caupi no Brasil: produção, melhoramento genético, avanços e desafios. Teresina: Embrapa Meio Norte, $2011.84 p$.

HAFIZ, N.A. Use of life tables to asses host plant resistance in cowpea to Aphis craccivora koch (homoptera: aphididae). Assiut University Bulletin for Environmental Researches, v.9, n. 1, p.16, 2006.

ILHARCO, F.A. Equilíbrio biológico de afídeos. Braga: Fundação Calouste Gulbenkian, 1992. 303p.

JALALIPOUR, R.; SAHRAGARD, A.; MADAHI, K.; KARIMI-MALATI, A. Comparative life table of Aphis craccivora (Hemiptera: Aphididae) on host plant, Robinia pseudoacacia under natural and laboratory conditions. Journal of Entomological Society of Iran, v.36, n.4, p.249-257, 2017.

MAIA, A.H.N.; LUIZ, A.J.B.; CAMPANHOLA, C. Statistical Inference on Associated Fertility Life Parameters Using Jackknife Technique: Computational Aspects. Joumal of Economic Entomology,v.93,n.2, p.51 1518, 2000. https://dx.doi.org/10.1603/0022-0493-93.2.511
OBOPILE, M.; OSITILE, B. Life table and population parameters of cowpea aphid, Aphis craccivora Koch. (Homoptera: Aphididae) on Five cowpea Vigna unguiculata (L. Walp.) varieties. Journal of Pest Science, v.83, p.9-14, 2010.

OLIVEIRA, C.R.R. Reação de genótipos de feijão-caupi às coinfecções pelo Cucumber mosaic virus, Cowpea aphid-borne mosaic virus e Cowpea severe mosaic vírus. 2011 . 89f. Dissertation (Mestrado em Genética e Melhoramento) - Universidade Federal do Piauí, Teresina, 2011.

PENTEADO, R.S.C. Cinara atlantica (WILSON) (HEMIPTERA, APHIDIDAE): um estudo de biologia e associações. 2007. 250f. Thesis (Doutorado em Ciências Biológicas) - Universidade Federal do Paraná, Curitiba, 2007.

PETTERSSON, J.; KARUNARATNE, S.; AHMED, E.; KUMAR, V. The cowpea aphid, Aphis craccivora, host plant odours and pheromones. Entomologia Experimentalis et Applicata, v.88, p.177-184, 1998. https://dx.doi.org/10.1046/j.1570-7458.1998.00360.x

SILVEIRA NETO, S.; NAKANO, O.; BARBIN, D.; VILLA NOVA, N.A. Manual de ecologia dos insetos. São Paulo: Agronômica Ceres, 1976. 419p.

SINGH, S.R.; JACKAI, L.E.N. Insect pests of cowpea in Africa: their life cycle, economic importance, and potential for control. In: SINGH, S.R; RACHIE, R.O. Cowpea research, production, and utilization. Chichester, New York: John Wiley and Sons, 1985. p. 217-231.

TRUDGILL, D.L. Why do tropical poikilothermic organisms tend to have higher threshold temperature for development than temperate ones? Functional Ecology, v.9, n. 1, p.136-137, 1995. http://dx.doi.org/10.2307/2390101

TRUDGILL, D.L.; PERRY, J.N. Thermal time and ecological strategies a unifying hypothesis. Annals Applied Biology, v. 125, n.3, p.521532, 1994. https://doi.org/10.1111/j.1744-7348.1994. tb04989.x

WILSON, L.T.; BARNETT, W.W. Degree-days: an aid in crop and pest management. California Agriculture, v.37, n.1, p.4-7, 1983.

VALENTE, E.C.N.; TRINDADE, R.C.P.; BROGLIO, S.M.F.; DUARTE, A.G.; RODRIGUES, V.M.; LIMA, H.M.A.; BATISTA, N.S.; SANTOS, J.R. Aspectos biológicos de Aphis craccivora KOCH (Hemiptera: Aphididae) em cultivares de feijão-caupi Vigna unguiculata (L.) WALP. Ciência Agrícola, v. 12, n. 1, p.17-20, 2014. http://dx.doi. org/10.28998/rca.v12i 1.1072

ZHAOZHI, L.; LIKAI, F.; GUIZHEN, G.; LING-LING, G.; HAN, P.; SHARMA, S.; ZALUCKI, M.P. Differences in the high-temperature tolerance of Aphis craccivora (Hemiptera: Aphididae) on cotton and soybean: implications for ecological niche switching among hosts. The Japanese Society of Applied Entomology and Zoology, v.52, n. 1, p.9-18, 2016. https://dx.doi.org/10.1007/s13355-016-0446-z 